\title{
Books and Book-Form in Milton
}

John K. Hale

Résumé : Comment Milton voyait-il les livres, dans le sens littéral ainsi que métaphorique de "voir »? Pour lui, comme pour Goethe, les livres impliquaient plusieurs aspects de la vie; ainsi il se sert de lieux communs traditionnels mais aussi de subtilités bibliographiques, ceux-là pour s'exprimer, celles-ci pour effectuer de la polémique caricaturale. Ces deux côtés de son engagement, avec d'autres, sont documentés dans le présent article à travers les genres et les langues de son écriture. C'était un intermédiaire multilingue, le dernier des anciens et dans les premiers rangs des nouveaux.

Given the connections we feel between an "early modern" period and J "print culture," we naturally ask how Milton viewed printed books, together with the particular forms of the book as printed. Did he have a constant, or changing, or ad hoc or literal or metaphorical, perception of the book? But the question needs careful definitions, and some recognition of work already done, before any general answering begins.

To take the matter of recognition first, J. W. Saunders has explored Milton's changing attitude towards publication, arguing that in the tumultuous 1640s (and because of them) Milton changed from an older, more gentlemanly preference for manuscript publication to a commitment to present his views and himself in print. ${ }^{1}$ D. F. McKenzie situates Milton's practice of print-utterance amongst the dialogic mid-century nexus of "Speech - Manuscript - Print."2 Neil Fraistat and others, including myself, have examined Milton's part in the self-presentation by means of print which is Poems, $1645 .{ }^{3}$ And this work continues in the writings of Stella Revard and Stephen Dobranski. ${ }^{4}$ Most of it, however, examines one or another portion of Milton's whole oeuvre. In this context, then, I see an opportunity to present 
a wider array of the primary evidence about Milton's perception - or perceptions - of books and their form, whether printed or other.

As to definitions, the notion of "perception" is better than the vaguer "attitude" used above. Milton sharply observed the physical object, and its parts and attributes, as expressions of collaborative endeavour and personality. He continued this literal sense of perceiving, aurally, even after he went blind. But his metaphorical perceiving is equally prevalent and energizing: major portion of my survey is given to his imaging of books, whether as people by personification, or as something else by his teeming metaphors and metonymies. The survey may suggest fresh lines of inquiry, not only about Milton but also about early-modern communicativeness.

I start with Milton's most famously rhetorical perceptions, in Areopagitica - a locus classicus for themes of general liberty, as well as for the more particular perceptions which concern us here. Here is where he justifies the accolade bestowed by McKenzie, that by 1644 the press "had begun to create a parliament without walls, and Areopagitica was the first eloquent voice to be heard in it." 5 I pursue these perceptions next into his prose of the 1640s, then his Poems of 1645, after which I probe the origins of these virtually credal acts of commitment of the 1640 s, when he found his public voice through his books. I then come to the major English poems, which are naturally taken as the testing or extending or completing of his utterances in prose or lesser verse. Yet are they, from our standpoint, sui generis, untypical, and less of their age? And do they look forward or back?

\section{The Perception of Books in Areopagitica}

Milton perceives books intensely by perceiving them in images. In case his most famous ones are staled by familiarity and partial quotation, I give the locus classicus in full and note its logic of qualifications, in order to defamiliarize the images and so restore their centrality:

I deny not, but that it is of greatest concernment in the Church and Commonwealth, to have a vigilant eye how Bookes demeane themselves as well as men; and thereafter to confine, imprison, and do sharpest justice on them as malefactors: For Books are not absolutely dead things, but doe contain a potencie of life in them to be as active as that soule was whose progeny they are; nay they do preserve as in a violl the purest efficacie and extraction of that living intellect that bred them. I know they are as lively, and as vigorously productive, as those fabulous Dragons teeth; and being sown up and down, may chance to spring up armed men. And yet on the other hand unlesse warinesse be us'd, as good almost kill a Man as kill a good Book; who kills a Man kills a reasonable creature, Gods Image; but hee who destroyes a good Booke, kills reason it selfe, kills the Image of God, as it were in the eye. Many a man lives a burden to the Earth; but a 
good Booke is the pretious life-blood of a master spirit, imbalm'd and treasur'd up on purpose to a life beyond life. ${ }^{6}$

The first sentence is ostensibly concessive ("I deny not"): governments naturally exercise vigilance towards books, for books have power, influence action, and may do harm, "as malefactors." But already concession turns into praise, since books "preserve" intellect as phials preserve medicines. The second sentence works in the same way: dragon's teeth in the myth of Cadmus image danger and violence, yet they led to his founding a city. The concessions contain their own concessions.

The rhetorical direction now becomes overt, in the amplitude of the awaited antithesis: "And yet on the other hand unlesse. ..." Milton makes his "Speech ... To the Parlament of England" in a crisis where censorship has gone too far, stifling the causes of reformation and of freedom. Qualifications are now over: Milton proclaims in his greatest image, a perception of books which he has already insinuated.

In the first sentence, books "demean themselves": they behave, well or badly, as persons do. Books "are not absolutely dead things" — not merely dead, not merely things. They live on, as the "progeny" of their authors, or rather ("nay") as their distilled, most efficacious essence (precious, sweetsmelling or medicinal).

The third sentence swings from insinuation to proclamation through imagery. The upper-case letters steer the perception as a whole: Man/Book, expanding into Man/Gods/Image//Booke/Image/God. The resemblance of books to men was commonplace: the hangman destroyed both when told to. But Milton rejuvenates the commonplace wondrously, suggesting that to destroy a good book "almost" equates with murder. It is an "almost" which stresses what it denies. The images are growing bolder all the time. If in the biblical account Man is God's express image (Gen. 1:26), it is through human reason; but a good book is more completely reasonable than its own author, it epitomizes reason. Thus, it seems, a good book is more fully God's Image than Man is.

Next, a good book is rapidly imaged as valuable, living, spiritual, and masterful, preserved and preserving, precious again, and deliberately aiming at immortality - posthumous reputation given religious force by the connotations of "life beyond life."

Just as Milton printed this blast against licensing without licensing it, and put his name defiantly on the title-page, so he perceived himself as putting a "good book" of his own into the company of the ones used on his title-page as exemplars. Those were, first, the Supplices of Euripides, Theseus' defence of a citizen's right to speak his mind on vital state matters; 
next, the "Areopagiticus" of Isocrates, a speech about policy designed to be read, not spoken; and, finally, Saint Paul's speech about God's words to the "men of Athens" "in the midst of Mars' hill" - the eponymous "Areopagus." Milton's perception of books rises to a bold rapture of self-presentation.

In other places of Areopagitica, and in other prose works of the 1640s, he images books in further ways, sometimes bizarre, but unfailingly energetic. Books may be monsters, sinners, what we see or hear, persons, Judgement, divine or human records, idlers, meats and viands, a diocese, a punishment. For Milton, as for Goethe, books enter into any life-relation, and may image any. ${ }^{8}$ Books, and writers, are Milton's heroes, as when he idealizes London itself, war-ready because it holds so many writers (equating the "pens and heads" of "the mansion house of liberty" with the "anvils and hammers" of the "shop of war" as means towards "the approaching Reformation"). 9

\section{Perceptions of Book-Form in the Prose, 1641-44}

Milton's heightened book-awareness received a more sidelong expression in his perception of book-form. While this is liveliest in imagery, as caricature, it also answers to a steadfast conviction of what books ought to be, and in fact are when unimpeded by human failings. He drubs his opponents by convicting them of maltreatment of such features as margins, title-pages and frontispieces; through this, however, we glimpse his ideas of the right form of the book itself, as object and idea.

First, he berates writers who overcrowd their margins with scriptural citations. Such writers "blur" the margin, they "cram" it and "stuff" it, as if this were cruelty to a defenceless creature, or an offence against readers' eyes. A glance at a page of one such writer, Robert Baillie, supports the complaint. On the page where Baillie attacks Milton by name, the biblical quotations make a bloated block, tight up against his exposition. ${ }^{10}$ They so distract the reader, from text to citation, that the eye cannot travel forwards. Milton makes an aesthetic and functional point, of some importance for the welfare and future of the reading act itself. More often, he fulminates in moral and intellectual terms: such marginalia are "crutches," they inflict "gout and dropsy" on the margins; proof requires more than a margin "littered and overlaid with crude and huddled quotations." speaking combatively, and holds more against such writers than aesthetic misdemeanours - for example, seeing their over-reliance on cited authorities as a denial of free thought and gospel liberties. Yet the aesthetic perception is the starting-point and figuring of his scorn, as much as to say, 
"Agree with me that the page suffers an obtuse physical disfigurement, and hence also dismiss the page's contents as obtuse." Is there not some implicit perception that readers have rights, such as the right to a legible and eye-pleasing page of print?

If margins might not merit such fervent defending, Milton makes a stronger defence more strongly with title-pages, lambasting all Imprimaturs. If a single Imprimatur is disgusting, think what five will do to Milton's moral nostrils:

Sometimes five Imprimaturs are seen together dialogue-wise in the Piatza of one Title-page, complementing [sic] and ducking each to other with their shav'n reverences. ${ }^{12}$

The imprimaturs become Italian clerics, bowing obsequiously to one another, as if the title-page were spiritually captive in Rome. The imprimaturs intrude on the book itself, its thought. Far from commending it, they put it at disadvantage. And nowhere do they do this more than in a context of teaching and learning: "when every acute reader upon the first sight of a pedantick licence, will be ready with these words to ding the book a coits distance from him." 13 This captures, as a cartoon does, the actual moment when the intrusion turns a reader from absorption to rejection, and the book from a joy to a mere throwable thing. The licenser spoils the learning, alienates the reader, and saps the teacher's authority ("I hate a pupil teacher").

Whereas this ridicule of Italian authoritarianism is good-humoured, it was soon afterwards that Milton met the same intrusion at home, more angrily. An English licenser, Joseph Caryl, not merely put his imprimatur to a work attacking one of Milton's divorce writings, but added praise of it, because in his view it "answered" Milton's case "and with good reason confuted it." Hotly, Milton replied that the licenser was

not contented now to give his simple Imprimatur but brings his chair into the Title-leaf; [and] there sits and judges up or judges down what book hee pleases. ${ }^{14}$

He sounds less indignant about another feature of books, indexes. Literal indexes, in the plain sense of word-lists, infringe readers' rights: they distort readers into "the ferrets and mousehunts [weasels] of an Index."15 The point concerns how readers should, and should not, use books to learn with. Indexes in the other sense, lists of books banned by heavy orthodoxy, arouse ire: they are "expurgatorious." 16 The adjective is a coinage, and may have as a conative aspect the expurgator's itch to ban, or be hinting that a reformed nation should have thrown out this Catholic practice along with the doctrine of Purgatory. 
The tone of each image varies, according to the occasion and audience of each prose work; the purport, however, remains constant, that books are the life and health of the mind, not lightly to be banned or burned by authority. Such authority is perceived with anger or ridicule. One last quotation shows Milton ridiculing. Whereas the angry Juvenal had asked who would censor the censors, Milton makes the point in a homely, humorous image, of a regiment of snoops pausing suspiciously in front of a shop window:

The Windows also, and the Balcone's, must be thought on, there are shrewd books, with dangerous Frontispices set to sale; who shall prohibit them, shall twenty licensers? ${ }^{17}$

He sarcastically sympathizes with the functionaries, faced with so many seductive title-pages, displayed like harlots on balconies.

\section{Self-Perception through Books and Book-Form: Milton's Poems, 1645}

Milton writes with such conviction and verve in the prose works of 1641-44 because books and book-form have entered his sense of vocation. These polemics on hot issues are part of what he was born for. But only part, and next - still very much nel mezzo del cammin di nostra vita - he perceives books in a wider way. In editing his poems of 1623-44 for print, he considers his own works as if asking, "How shall I present myself as a poet in this book of mine?"

None of the poems included in the volume was written for it, and most were not even recent. It looks back on a self accumulated, in part, by these poems - a poetic self never before acknowledged in print over his own name. Such is suggested, too, by a poem about the book after its publication, and his perception there of his book and himself. The full, elaborate preliminaries - those in English and those in Latin - show precisely the care Milton took with the impression made by the book as book; they challenge admiration yet mitigate any envy or charges of arrogance. Numerous features of book-form, by their originality and exactness, bear witness to a self-summarizing, self-presenting purpose. Not only is he aware of the act of selfediting, but he recognizes an emergent self through that distinct, retrospective act.

Milton as self-editor gives the age at which some poems were composed, yet not in every case. The procedure enables him to excuse poems which are juvenile, like Elegia VII, or uncompleted as being "above the years he had when he wrote it," like the ode on the Passion. It enables him to take pride in what he did achieve even at those years ("done by the Author at fifteen years old"). We may applaud and enjoy the editorial balancing act. 
Equally, however, we note that poems equally early are presented without any plea in mitigation, to be read on their timeless merits: thus he begins his English poems with the Nativity Ode, closes them with Lycidas, and follows up hard with $A$ Masque, given its own title-page and commendations. The placing of these major poems attests the editor's sense of what he is to be judged by, which poems are to be perceived as the self's writerly accomplishment; thence is to come the reader's still provisional, but gathering, sense of an oeuvre.

Of this sense, the English poems furnish only half. Milton sets Italian sonnets within his sequence of English ones - surprising his first readers into the perception that this self is multilingual in its accomplishment. And in the Poemata, with its distinctive ordonnance, a wider multilingual accomplishment is to be inferred. They comprise a series of "Elegiae" (elegiac couplets, subdivided into an Ovidian series with palinode, then a series of epigrams). The "Sylvae" which follow emulate Statius as originator of this genre of mixed metres and modes; but Milton is his own man again, moving through acknowledged juvenilia (and three Greek poems when least expected) to a series of increasingly major hexameters. These being in Virgil's metre, and the last being saturated in Virgil's eclogues and ancient lament-poetry, vindicate the Virgilian appeal made on the title-page (to be discussed shortly).

The poem Milton wrote to Bodley's Librarian, John Rouse, about his 1645 volume confirms these inferences about his editorial action. It excuses and takes proper pride. It sees the poems as progeny: to be exact, an unusual because twin - bilingual - progeny. It glides from the past to the future. But the vate is futuro in a different sense now: the poet's future is assured of reputation, not if he surpasses these poems by later greater ones, but simply if the Poems reach Bodley. They will thus join all great and good books held there by Rouse as an Ion, guardian of books as a holy treasure. The lightness of tone does not conceal Milton's pleasure in knowing that his poems along with his works of prose controversy - will now be conserved in Bodley as the centre of Oxford, as the centre of the intellectual life.

The double preliminaries show the same combination of defence and appeal, as much as to say "only give me a hearing." Yet some anxiety is shown on this score. The first title-page cites Virgil, to acknowledge the classic exemplar. But since this was customary, we notice the particular tag: 
No one knows what plant "baccare" refers to, nor what Milton thought it referred to. Antidote to the evil eye, or tongue, it must be: Milton sees ways in which his bold volume may backfire. As he begins the quotation after the lines (25-26) where Virgil's singer Thyrsis demands praise from his audience of shepherds, Milton's is not a simple appeal for applause.

Book-form contributes similarly. The size and length and scope, the shape and size of page, are none of them lavish. They enliven the basic form, as when Italian verses are given in italics, or the balances are recognized (English against Latin; Elegiae against Sylvae within the Latin; Comus against the rest within the vernaculars). ${ }^{18}$ The self presented is an alert, book-conscious persona, creative and emphatic in exploiting the medium of print.

Books "compose the self . . . / For if we use / Words to maintain the actions that we choose, / Our words, with slow defining influence, / Stay to mark out our chosen lineaments." 19 A book may help truth, and bring reputation, but - in between these most impersonal and most personal of motives - it implies the author's intellectual self-picture, his standards of judgement, self-criticism, self-awareness.

\section{Milton as a Reader, to $\mathbf{1 6 4 5}$}

Milton had a physical problem with perceiving: he inherited bad eyesight from his mother's side, and made it worse through years of late reading by candlelight. But, his father being a scrivener, Milton lived among papers and knew their contractual power. He read diverse systems of symbols: music, early, and besides the usual alphabet those of Greek, Hebrew, and Syriac. Languages comprised a large portion of his reading, from school onwards: his reading was for learning and by access to originals. He read to a system, excerpting into a commonplace book, Greek and Latin wordbooks, and notebooks for theology, ethics, politics. For a few texts he annotated as he read, writing in the margins, for instance, of his copies of Greek poets. Of all his reading acts, these marginal ones reveal most: we look over his shoulder as he grapples with the complexities of emendation or sense or reference, in active dialogue with previous editors or Euripides himself. These reading acts, repeated over two decades for the Aratus and Euripides copies, are not done for any further purpose but for philaletheia, truth's sake. ${ }^{20}$ Milton's perception of books is here at its most intrinsic, is most itself - unviolated by preconceptions or the needs of occasion.

So much for his acts of reading. What about his earliest acts of writing? He came very early to an acute self-awareness of himself interacting with books in the act of writing. In the Nativity Ode, for example, written on his 
twenty-first birthday, he envisages the poem as his gift to the baby, and himself running to lay it at Christ's "blessed feet" before the Magi can give their more impressive gifts. The trope of proud modesty anticipates its counterpart in editing Poems, 1645. Similarly, in his Italian sonnets he makes a central motif of himself in the act of writing in Italian to praise an Italian lady. If this is a foretaste of the intense subjectivity of his best work, his egotistical sublime, it emerges early in these acts of book-awareness, which for their part help to give it varied forms of expression.

Whereas such awareness is a constant in Milton's life, we move now to a puzzle, one which, whilst appearing minor, leads to a seminal perceptual change. His Latin poems are little read nowadays, and indeed are for the most part early and minor. They show him again aware of himself, as in personifying a verse-letter which is to speak for its "father" to the friend addressed, or laying Latin itself in the grave of his closest friend.

Till the crisis of church and state in the 1640s Milton thought of writing as something done for friends and them only, although friends included any cultivated persons who might solicit or be given copies of a poem in manuscript. Till 1642 Milton prints, if he prints, anonymously, and his poems circulate most often in manuscript. So like Spenser in his ideals and religious stance, Milton is unlike Spenser in his perception of print. And when Milton does discover print and put his name on title-pages, he still does it for individual reasons - not for money, but to propagate his views, to silence canards about the authorship. Especially, he does it in order to place his complimentary copies strategically. He targets friends, native and Italian, and librarians (Bodley's and the King's). Rouse asked for the prose works, and Milton added the poems. Young was sent both kinds. A set of the pamphlets went to Hanover. ${ }^{21}$

These changes in Milton's conception of "publication" have an element of the contingent. He first puts his name to an antiprelatical work in 1642, and again to a divorce tract in 1644, to defy the opposition's dark insinuations about its author. But having broken cover, he discovers author-status with a vengeance. Areopagitica may have been a landmark, in that an "oration" to Parliament printed anonymously might look quaint or pusillanimous. A little earlier, he had published the open letter to Hartlib "Of Education." And so to Poems of Mr John Milton, Both English and Latin, 1645, in which print fashions the multilingual self. 


\section{After 1645}

The next twenty years need not be followed in detail. Milton appeared in print by name mainly when defending Parliament, whether internally in English or in Latin to Europe. Yet at times he stayed anonymous.

The more important fact of the period is that Milton went blind. This did not at first propel him back to an enforced otium, cultivated leisure. But it certainly affected how he perceived books and book-form. He says something about this in his letters, how books have proved to be his weapon of Telephus - the cause of his sickness, which yet he does not blame. And since the myth of Telephus hinges on the ending, in which the weapon of his injury heals him, Milton means that books caused his blindness yet remain life and healing to him. ${ }^{22}$

Moving from the obvious to the speculative, can we say how blindness affected his reading? Avid, lifelong readers who have gone blind record how they still devour print as best they may. They often rely on teams of readers. I am sure Milton did this, having both general and specialist readers to keep him going (respectively, his daughters, and the man who came to read him from the Hebrew Bible daily). On the other hand, reading aloud is different from one's own reading - much slower, compelling a different kind of attention. Milton may have settled for hearing his favourite authors most: the Hebrew Bible, and the poets mentioned. But he also ran a sort of think-tank or laboratory, in which groups of ex-pupils or other helpers read texts to him and wrote down his responses at dictation, in pursuance of large semi-collaborative projects like the two dictionaries or the De Doctrina Christiana. He kept up his reading, and he kept up the many purposes of his reading.

If anything, blindness made him more of a writer than a reader. He kept writing, even if it meant using amanuenses who knew no Latin and to whom he must dictate the individual letters of each word. ${ }^{23}$ Many writers, though, as they gain confidence from publication and reputation, read less and write more. The period 1660 to his death is the period of all three of his greatest poems - the works which in the last analysis make Milton Milton together with his History of Britain, which won him equal contemporary reputation, and a rapid succession of smaller works and revisions. In the last seven years of his life, Milton's study was a powerhouse.

\section{VI. $1660-74$}

Paradise Lost, notwithstanding its origins in the 1640 s, is mainly the work of Milton's blindness. Does it show any signs of a changed attitude towards 
books, and especially physical book-form? There are changes, indeed surprises.

The books of epic predecessors are of course part of the poem's massive allusiveness; but the books are mentioned as authors, not objects. Tellingly, the Bible itself, the "book" par excellence ${ }^{24}$ and Milton's source for so much in the epic, is not referred to by name nor yet as "the Book." Instead, on the one hand, the constituent books of the Bible are called its "voices"; and on the other hand, the books of God are the old metaphorical, tropical ones. ${ }^{25}$ That is, the book of the Apocalypse is adduced as the "voice" of John (4.1), while the "book of God" is either the "book of knowledge fair" (3.57) or "heaven" (8.67). Books as such, book-form, even the Bible as revealed truth, do not stand out in the texture: heaven's "frontispiece" means its portal, in the older architectural sense of the word. Blindness made Milton, if anything, more vocal, more oral. Naturally so, too, since he is emulating the blind Homer, and relying on the voice of his Muse to lift him from the despondency of outward failure (3.26-55) and the "depressing" of his "wing" (9.45-46).

This should not be misunderstood as a forswearing of the book-love illustrated earlier. Far from it. The proofs of the poem were assiduously corrected, more than for earlier works. Milton altered, revised, expanded, and cared for his poem through serial improvements up to his death. ${ }^{26}$ If he organized the proof-reading differently, blindness may actually have helped: a writer who is blind must insist on the slow, collaborative reading-aloud which sighted writers short-circuit at their peril.

The epic's limited use of book-tropes may solve or ease a controversy about its intended readership. If the only explicit references to books in the poem are to the older book-tropes, that might mean the poem looks backwards, to the common stock of topoi deriving from antiquity, accessible to any educated reader. It would do so without losing the other desired readership, the plain Protestants (having a bad time of it, like Milton, under the Restoration), because they would pick up the particular allusions well enough; besides, Milton makes sure they do, by perpetual pithy glossing within his text. The poem is learned yet accessible, not an outlet for arcane theology.

As regards the traditional book-topoi, Milton does not lean on them: he appropriates them, and renews them, with the verve and flair we expect from the poet who was always so aware of books and of himself in the act of making them. Thus he does not baldly equate Nature with the book of God, lost to him through physical blindness. He says this only as part of making the topos spiritual, dynamic, and his own. The "book of knowledge fair" (3.47.) uses the topos of nature as God's book, but the word order ascribes 
beauty to the book and the knowledge, by placement of the adjective "fair." The pun is the act of appropriating, imitatio become energizing. Again, when the book becomes a "universal blank" to the blind poet (48), that means both a literal empty white page and an unmeaning void. And why blindness matters is because it spells loss of wisdom, "wisdom at one entrance quite shut out" (50). Sight, and the reading of this book, are never so well perceived as in the mental act of knowing them lost. Again, when Adam is told that "heaven / Is as the book of God before thee set" (8.66-67), this says more than that the natural world is the book of God. For Milton here, heaven is the book of God visible as eternity, the sublimity at the heart of astronomy. So the age-old topoi are rejuvenated.

Books receive a different sort of mention in Paradise Regained. Messiah quotes Ecclesiasticus, to the effect that "many books / Are wearisome" (3.321-22), and deplores a reader "Deep-versed in books and shallow in himself" (327). The first critique alters the Bible, which had said "Of making many books there is no end; and much study is a weariness of the flesh." 27 The other points to the occupational hazard of writers and readers. Was Milton thinking of his own unfinished or futile projects? If so, which ones?

There is much else about these final years which is surprising or unclear. Why did he not finish and publish his dictionary projects? Why, rather, did he finish his Grammar and Logic? Why did he change publisher so often? Why is the History of Britain a larger and finer volume than his other books (excepting the Defences, as paid for by the Government)? Did he positively favour cheap plain little books, as more vendible and accessible, or did he care only for the thought-content of a book? He certainly corrects the pointing of his Latin poems in 1673 , in a case where pointing ruins meaning. ${ }^{28}$ The "Errata" there suggest an author who is vigilant whenever meaning is concerned, yet then only. Is print, for Milton, communication first and last? Does clear and direct communication outweigh beauty and every other consideration? Always or sometimes?

\section{Conclusions, Speculations and Further Questions}

To attempt first some answers to the questions I began by posing: Milton seems especially aware of books, as objects, media, symbols, expressions of selfhood. In writing of them he makes us similarly aware. This is a constant.

But he is also transitional - among the last writers to use the older book-tropes and the first to create new, print-based ones. Working from a still largely oral and manuscript culture, he seeks as a humanist to perform all the roles expected of a latterday Cicero, yet uses print to try out new personae, new voices. And he addresses very diverse auditories - to gain 
fame among an elite, to influence public policy, and to teach at all levels. He has grasped the flexibility of print as medium.

Though class-bound in many assumptions, he uses print to widen his readership and influence - and most in Paradise Lost. In a similar spirit, his advocacy of freedom involves print, as a source and condition of other freedoms: freedoms are connected.

$\mathrm{He}$ is the most eloquent celebrator of books as such, till Italo Calvino. Though he blamed them for ruining his eyesight, he was not angry with them, for he likened books in the broadest sense ("literis") to the weapon of Telephus, "qui eo telo, quo vulneratus est, sanari postea non recusavit" [From the weapon which wounded him, he afterwards accepted healing] $]^{29}$; and "afterwards" (postea) means not least in his late outpouring of printed books of all sorts, as an almost-completed presentation of a self and its life.

Milton's perception of printed books is evidently greater when he is conducting controversy about and by means of books; for instance, he adjusts his register at such times not only to a coarser polemic but to a greater degree of book-related particularity. Yet he does this not merely in order to convince or to vivify, but in a way that is figurative. Book-details, on the one hand, figure by synecdoche or metonymy for whole books or their authors (and printers and backers and other affines in the mid-century book-wars). And book-details provide a teeming resource for metaphors, be they caricatures of the Papacy or symbols of the one good fight. Such figures achieved by exact detail are new. The book, on the other hand, is likely to carry with it older and more traditional connotations, especially in poems in higher registers. One can perhaps test and confirm this distinction, of the symbolic or topical use of the book from the printed book in its detail, by seeing how he presents his own first book of poems, in the Ode to Rouse. He refers to Poems, 1645 as "Gemelle ... Liber," in which designation "Liber" continues the old or generic name but adapts the current trope or cliché of the book as "offspring" to the special "twin" birth (bilingualism) of his. ${ }^{30}$ By a different defamiliarization he then changes the classical term "frontes" - edges of the papyrus-roll at each end, the term used by Ovid and others - to "frondes" - the "leaves" of the contemporary (as yet unbound) book. ${ }^{31}$ Milton, then, in his perception of the book is both ancient and modern.

Finally, let us revert to Ernst Robert Curtius and his study of book-topoi. He speculates that the book "no longer possesses a unique, a felt, a conscious 'life-relationship,' [and] could no longer possess it after the Enlightenment shattered the authority of the book and the Technological Age changed all the relations of life." 32 But when we look at the case of Milton some hundred years earlier, we find both continuity and innovation in the symbolism of the 
book, as entering into diverse life-relations. Are we looking at a last late flowering, and a first symbolic particularity - early modern indeed?

\author{
University of Otago
}

\title{
Notes
}

1. J. W. Saunders, The Profession of English Letters (London: Routledge, 1964).

2. D. F. McKenzie, "Speech - Manuscript - Print," Library Chronicle of the University of Texas at Austin 20 (1990): 86-109.

3. Neil Fraistat, The Poem and the Book: Interpreting Collections of Romantic Poetry (Chapel Hill: University of North Carolina Press, 1985); Louis L. Martz, Milton: Poet of Exile, 2nd ed. (New Haven: Yale University Press, 1986); John K. Hale, "Milton's Self-Presentation in Poems . . 1645," Milton Quarterly 25.2 (1991): 37-48.

4. Stella Revard, Milton and the Tangles of Neaera's Hair: The Making of the 1645 Poems (Columbia: University of Missouri Press, 1997); and Stephen B. Dobranski in a series of essays, esp. "Letter and Spirit in Milton's Areopagitica," Milton Studies 32 (1995): 131-52. See also the latter's Milton, Authorship, and the Book Trade (Cambridge: Cambridge University Press, 1999).

5. D. F. McKenzie, "Printing in England from Caxton to Milton," in The Age of Shakespeare, vol. 2 of The New Pelican Guide to English Literature, ed. Boris Ford (London: Penguin, 1982).

6. Milton is quoted or cited from the Columbia edition, qua latest complete Milton: The Works of John Milton, gen. ed. Frank Allen Patterson, 18 vols. (New York: Columbia University Press, 1931-38), with Index (2 vols.; 1940). These are abbreviated henceforth to "ColWorks" and "ColWorksIndex." The passage in the text is ColWorks, 4: 297-98.

7. Acts 17:22 (King James Version given). It has been doubted whether Paul's Areopagus comes into Milton's view, but I accept Ernest Sirluck's reasoning in his edition of Areopagitica for vol. 4 of Don M. Wolfe et al., eds., Complete Prose Works of John Milton, 8 vols. (New Haven: Yale University Press, 1953-82). The context in Acts 17 is of free speech, by a believer amongst the sceptical or superstitious, which concludes with the conversion of, amongst others, Dionysius the Areopagite (17:34).

8. The images are drawn from ColWorksIndex, entries from the 1640s English prose. On books as a figuring of life-relations in the thought of Goethe, see E. R. Curtius, European Literature and the Latin Middle Ages, trans. Willard R. Trask (New York: Harper \& Row, 1963), ch. 16, esp. pp. 303 and 347.

9. ColWorks, 4: 340-41.

10. Robert Baillie, A Dissuasive from the Errours of the Time (London: Samuel Gellibrand, 1646), attacking Milton's Doctrine and Discipline of Divorce (1644).

11. See the entries "margins" and "margent" in A Concordance to the English Prose of John Milton, gen. eds. Laurence Sterne and Harold H. Kollmeier (Binghamton, NY: MRTS, 1985).

12. ColWorks, 4: 304

13. ColWorks, $4: 340-41$ 
14. ColWorks, 4: 238-39 (Colasterion, 1645).

15. ColWorks, 3: 35 (Of Reformation, 1641).

16. ColWorks, 3: 112 (Animadversions, 1641).

17. ColWorks, 4: 317 (Areopagitica).

18. Though not all of this is necessarily the author's idea, some if not most of it surely is. It may be the collaborative book-form perception of Milton and his printer.

19. Thom Gunn, "To Yvor Winters, 1955," in Poems 1950-1966: A Selection (London: Faber, 1966), p. 22.

20. I discuss these in John K. Hale, "Milton's Euripidean Marginalia: Their significance for Milton Studies," in Milton Studies 27 (1991): 23-35, and in ch. 4 of Milton's Languages: The Impact of Multilingualism on Style (Cambridge: Cambridge University Press, 1997).

21. See William Riley Parker, Milton: A Biography, 2 vols. (Oxford: Clarendon Press, 1968), p. 932.

22. ColWorks, 12: 86 (Letter 21, cited more fully below).

23. As he complains in Letter 31 of Epistulae Familiares (ColWorks, 12: 115).

24. The history of usage of "Bublos" or "Biblion" in Greek traverses (i) document, (ii) book, (iii) a book as part of a larger work, and so (iv) the "books" which make up the Bible, e.g., Septuagint Malachi 12:9. Mark 12:26 has the "book of Moses," Philippians 4:3 the "Book of Life"; $c f$. Psalms 69:28.

25. He uses the vaguer word "records" to refer to biblical historiography ( $P L$ 12.513).

26. See John K. Hale, "Paradise Lost: A Poem in Twelve Books, or Ten?", Philological Quarterly 74 (1995): 131-49.

27. Ecclesiastes 12:12.

28. In Quintum Novembris, 149-50 (ColWorks, 1.1: 248).

29. ColWorks, 12: 86 (translation mine).

30. “Ad Joannem Rousium," 1-2 (ColWorks, 1.1: 316).

31. So Walter MacKellar, followed by Douglas Bush, $A$ Variorum Commentary on the Poems of John Milton, vol. 1, ed. Douglas Bush (New York: Columbia University Press, 1970), p. 327.

32. Curtius, p. 347. 